Светлана Јанчић

UDK 02:061.2(497.11)"1947/2017"

https://doi.org/10.18485/

bibliotekar.2018.60.1.7

\title{
НАШИХ СЕДАМДЕСЕТ ГОДИНА
}

\section{Свечана беседа поводом обележавања седамдесет година од оснивања Библиотекарског друштва Србије 1947-2017}

У још увек неиспричаној причи о почецима, развојној линији, дометима и будућим стремљењима српског библиотекарства у контексту националне, друштвене и културне историје, заснованој на целовитом и научно утемељеном приступу, једно важно поглавље тек чека свога хроничара - поглавље о коренима и професионалном деловању Библиотекарског друштва Србије чијих седамдесет година преданог рада данас свечано обележавамо.

Богата и разуђена грађа о активностима Друштва један је од важних извора за проучавање историје српског библиотекарства у периоду од 1945. године до данашњих дана. Све значајне промене у домену парадигме библиотеке и библиотекарства, све иновације у концептуалној и процедуралној равни праћене интернационализацијом делатности, сва друштвена превирања, кризе, преокрети у систему вредности, редефинисање културног модела и транзициони процеси - све се то преломило у последњих седам деценија кроз рад Друштва, чинећи га активним учесником у најзначајнијим променама у дискурсу српског библиотекарства, на теоријском, организационом и вредносном плану. Између почетне и крајње тачке овог координантног система - од којих прва означава библиотеку у функцији идејнопропагандног и културно-просветног рада, а друга библиотеку као приступни интерфејс глобалном универзуму информација - одвијали су се комплексни процеси модернизације и изграђивања српског библиотекарства као јединственог и интегрисаног система.

Та динамична линија развоја отпочела је послератном обновом, организационим и стручним јачањем библиотека, њиховим умрежавањем, нормативно-правним утемељењем делатности, да би седамдесетих година 
прошлога века добила нов замах укључивањем у међународне стручне токове, успостављањем концепта Универзалне библиографске контроле, Универзалне доступности публикација, усвајањем међународних стандарда за обраду библиотечке грађе и изградњом аутоматизованог библиотечко-информационог система у ОРАС окружењу. Даљи пут ка библиотеци без зидова, водио је ка редефинисању библиографских начела и циљева, померању тежишта са унифицираног на контролисани приступ креирању и управљању метаинформацијама, формирању новог библиографског језика, заснованог на семантици информатичког лексичког корпуса и, у најширем контексту, ка преиспитивању професионалног идентитета и улоге библиотека у дигиталном окружењу.

Све те промене у протеклом динамичном и амбивалентном временском периоду на размеђу два миленијума покренуле су, оствариле и настављају да их осмишљавају и реализују генерације библиотекара, марљивих и преданих сакупљача, обрађивача, чувара и промотера забележеног знања. Иницијативом најугледнијих међу њима, у периоду од 1921. до почетка 1941. године основана је и деловала Београдска секција Друштва југословенских библиотекара, по покренутим иницијативама и професионалним акцијама најактивнија и најбројнија секција Друштва. Осветљавајући ово раздобље узлета српског библиотекарства, проф. др Гордана Стокић Симончић у

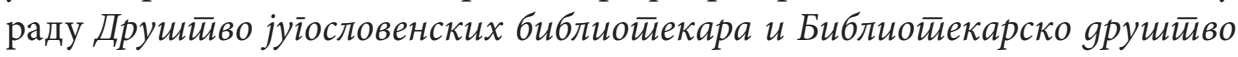

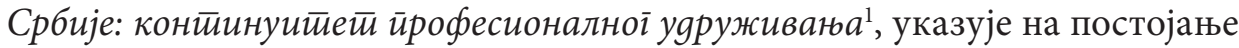
и рад струковне асоцијације која је представљала прву етапу библиотекарског удруживања на југословенским просторима и претходницу Друштва библиотекара Србије. Визионарство њених чланова и циљеви за које су се залагали - оснивање средње библиотекарске школе, професионало усавршавање, покретање стручног часописа, успостављање међурепубличке и међународне сарадње, организовање библиотечке мреже, утврђивање јасно дефинисане типологије библиотека - уграђени су у темеље послератног развоја професије и приоритетне задатке будуће националне асоцијације.

Када је 14. децембра 1947. године, на оснивачкој скупштини одржаној у Универзитетској библиотеци „Светозар Марковић” у Београду, формирано Друштво библиотекара Народне Републике Србије, међу њеним оснивачима били су и библиотекари из међуратног периода. Из те сјајне плејаде пионира модерног српског библиотекарства подсетимо се имена

1 Гордана Стокић Симончић: „Друштво југословенских библиотекара и Библиотекарско

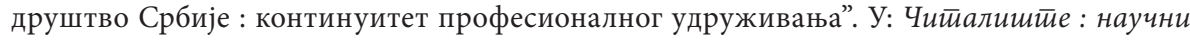
часойис за тиеорију и ирраксу библиотетекарстива год. 16, бр. 31, 2017, стр. 56-59. 
оснивача и најистакнутијих чланова нове асоцијације - чланова првог Управног одбора Друштва: Милице Продановић, председнице, Бисеније Лукић и Ђузе Радовића, потпредседника, Владимира Питовића, секретара; чланова Надзорног одбора: Александра Поповића, Милице Војиновић и Пауле Музер; чланова Суда части: Људмиле Михајловић, Јанка Договића и Јелене Маслеше. У надахнутом говору Милице Продановић, са акцентом на друштвенополитичкој функцији библиотека као сектора идејнопропагандног и просветног рада, трасирани су задаци Друштва, његова организација и методологија деловања. Усвојена Правила само су кодификовала кључне програмске активности: унапређење библиотекарства у Србији, развијање библиотечке мреже, оспособљавање и стручно усавршавање библиотечког кадра, издавање стручног часописа и стручних публикација, популарисање књиге и формирање читалачке публике, сарадња са сродним асоцијацијама и институцијама у националним и међународним оквирима, залагање за друштвену валоризацију статуса струке и очување угледа професије.

Развијајући своју делатност на темељима првобитног програма и проширујући и унапређујући делокруг и модалитете свога рада у оквиру секција, подружница, одбора, комисија и радних група, чије је програме обједињавао и усмеравао Извршни одбор, Друштво је иницирало и реализовало бројне пројекте који су оставили значајан траг у српској култури: покренуло издавање часописа Библиотекар, првог и најзначајнијег стручног гласила, уџбеника и приручника генерација библиотекара; активно учествовало у оснивању средње библиотекарске школе; залагало се за оснивање Катедре за библиотекарство на Филолошком факултету Универзитета у Београду која је конституисана 1963. године, да би две године касније била укинута; допринело развоју научноистраживачког рада у области библиотекарства, архивистике, документалистике и информатике; у сарадњи са Народном библиотеком Србије израдило програм за први Библиотечки центар, нуклеус матичне делатности на нивоу Републике; организовало бројна саветовања на националном и међународном нивоу о најактуелнијим темама у домену библиотечко-информационе делатности; одговорно и компетентно се укључило у доношење законских и подзаконских аката, норматива, прописа, стандарда, стратегија развоја делатности; покренуло оснивање Савеза друштава библиотекара Југославије под чијим су се окриљем, све до распада заједничке државе, решавала кључна питања од значаја за изградњу јединственог библиотечко-информационог система; подржало оснивање Заједнице југословенских национакних библиотека; развијало делотворну сарадњу са Iflom, FIAB-ом, Eblidom и другим 
сродним међународним асоцијацијама; подстицало решавање виталних стручних питања; предано радило на утемељењу кључних категорија етичког кодекса у коме су јасно изражене и системтизоване професионалне вредности, обавезе и права библиотекара.

Данас када прослављамо седамдесет година мисије једног од најугледнијих професионалних друштава Србије, желим да поделим са вама уверење - утемељено на привилегији да сам преко четири деценије била учесник и сведок коренитих промена библиотечког дискурса у националним и међународним оквирима и активни члан Друштва, његов секретар и дугогодишњи председник Републичке и Савезне комисије за каталогизацију - да виталност наше професије, њен друштвени статус и утицај зависе од наше спремности да своје циљеве прилагодимо технолошким и друштвеним променама, да омогућимо слободан приступ информацијама свима без разлике, да унапређујемо и оплемењујемо комуникацију са хетерогеним и све захтевнијим универзумом корисника, да се залажемо за интелектуалне слободе и транспарентност информација, да продубљујемо сазнања и ширимо интересовања, да непрекидно учимо, промовишући знање о знању, да чувамо и унапређујемо наше професионално јединство, снагу и углед институција, да успешно заступамо своје идеје и делотворно утичемо на доносиоце одлука, руковођени принципом општег добра и свешћу о друштвеној одговорности наше професије.

Зато је важно да - смишљајући „најбоље приче” и развијајући механизме који ће промовисати наше вредности, истичући наше присуство и значај, потенцирајући наше могућности, указујући на библиотеке као поуздане партнере и носиоце развоја и трансформације друштва - останемо усредсређени на промене, јер су оне, у свету који се вечно мења, једина извесност, да их пратимо и разумемо, да у сваком тренутку будемо способни да јасно и недвосмислено одлучимо шта од старог желимо да понесемо и уградимо у „универзум који неки називају библиотеком”, како би рекао Борхес, које речи желимо да запамтимо, којих корена се никада нећемо одрећи, које везе ћемо заувек сачувати, чија подршка ће нас оснажити, која сећања ће нас пратити на том путовању, на којем ће све оно што смо понели са собом као драгоцени дар доживети преображај и поново постати оно што јесте у једном новом времену.

У Београду, 14. децембра 2017 